ppi $201502 Z U 4645$

Esta publicación cientifica en formato digital es continuidad de la revista impresa ISSN-Versión Impresa 0798-1406 / ISSN-Versión on line 2542-3185Depósito legal pp

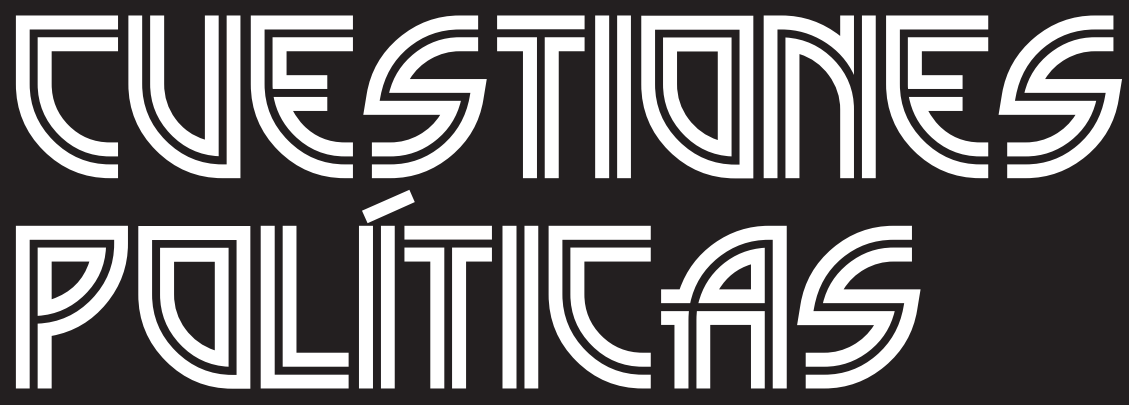

Instituto de Estudios Políticos y Derecho Público "Dr. Humberto J. La Roche' de la Facultad de Ciencias Jurídicas y Políticas de la Universidad del Zulia Maracaibo, Venezuela
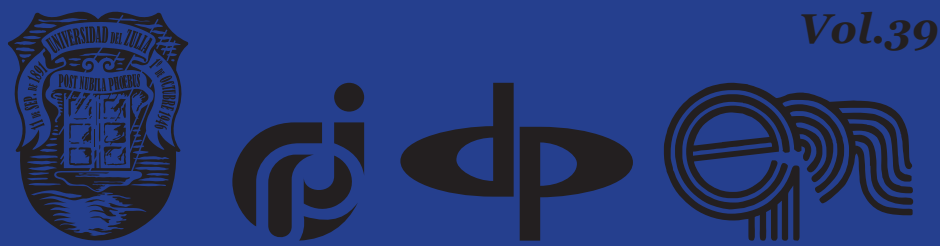


\title{
The Dynamic of Developing of the Relations between Russia and Great Britain during the President Vladimir Putin's Third Term (2012-2018)
}

\author{
DOI: https://doi.org/10.46398/cuestpol.3968.19
}

\author{
Vasil Timerjanovich Sakaev * \\ Oksana Sergeyevna Demianko ** \\ Rushana Alfredovna Faizullina ***
}

\begin{abstract}
The article looks into the features of Russo-British relations in the period from 2012 to 2018 during the third presidential term of Vladimir Putin. During this period, they went through several stages in their development from a period of alienation to almost direct confrontation. The authors reviewed the key events in the period under study in bilateral relations. The factors that played a leading role in the formation of relations at the present stage are also highlighted. The analysis of the position of the two States on various events, including Brexit, was conducted. The research is based on historical-descriptive and intuitive-logical methods. The analysis of the position of the two States on various events was conducted. The results obtained correspond to the conclusions of a number of researchers and expand the existing understanding of the nature of Russia's bilateral relations with leading Western Powers in the second decade of the XXI century.
\end{abstract}

Keywords: bilateral relations; Russia and Great Britain; foreign policy; relational crises; sanctions and negotiation.

Candidate of Historical Science, associate professor, Institute of International Relations, Kazan Federal University, ID Scopus: 57189332622. ORCID ID: https://orcid.org/oooo-0oo2-9921-3799. Email: vasil.sakaev@gmail.com

** BA, Institute of International Relations, Kazan Federal University. ORCID ID: https://orcid.org/ooooooo1-5540-0261. Email: demiankooksana@gmail.com

*** Assistant professor, Institute of International Relations, Kazan Federal University. ORCID ID: https:// orcid.org/oooo-0oo1-9196-0098. Email: rurinch@mail.ru 


\section{La dinámica del desarrollo de las relaciones entre Rusia y Gran Bretaña durante el tercer mandato del presidente Vladimir Putin (2012-2018)}

\section{Resumen}

El artículo analiza las características de las relaciones ruso-británicas en el período de 2012 a 2018 durante el tercer mandato presidencial de Rusia Vladimir Putin. Durante este período, las relaciones aludidas pasaron por varias etapas en su desarrollo desde un período de alienación hasta una confrontación casi directa. Los autores revisaron los hechos clave del período en estudio en las relaciones bilaterales. También se destacan los factores que jugaron un papel protagónico en la formación de relaciones en la etapa actual. Se realizó el análisis de la posición de los dos Estados sobre diversos hechos, incluido el Brexit. La investigación se basa en los métodos histórico-descriptivos e intuitivo-lógicos. Se realizó el análisis de la posición de los dos Estados sobre diversos hechos. Los resultados obtenidos corresponden a las conclusiones de varios investigadores y amplían el conocimiento existente sobre la naturaleza de las relaciones bilaterales de Rusia con las principales potencias occidentales en la segunda década del siglo XXI.

Palabras clave: relaciones bilaterales; Rusia y Gran Bretaña; política exterior; crisis relacionales; sanciones y negociación.

\section{Introduction}

Relations between Russia and the UK throughout their history have never been simple. There are several reasons for this. First, countries do not have enough principled foundations for sustained cooperation and genuine trust due to a lack of shared values. The leaders of both countries have different understanding of the meaning of democracy, supremacy of law, human rights, and state sovereignty. The crises in Libya, Syria, and Ukraine show that British and Russian foreign policy interests regularly diverge, and these contradictions may even be irreconcilable. In addition, relations between countries are burdened with a long historical baggage, not always with a positive context. Since 2010, a phase of relative calm in relations between Russia and the UK seemed to have begun after the coalition government led by David Cameron came to power in May this year. There are even positive features in the relations between the two countries. However, this lull did not last long.

In this article, the authors will try to give a retrospective analysis of the development of relations between the two countries, highlighting the stages of their development during the period and try to understand 
how significant this negative "baggage" is for the development of bilateral relations in the future.

\section{Methods}

The research is based on classic methods developed in the theory of international relations, namely historical-descriptive and intuitive-logical methods. They are best suited for solving the research problem set in the article. The source base for the study was made up of official documents of foreign ministries, public statements by the leaders of the two countries, and materials from the leading media.

\section{Results and Discussion}

As you know, in March 2012, elections were held in the Russian Federation, where Vladimir Putin won. Although British Prime Minister David Cameron congratulated Putin on his election victory over the phone and expressed hope for close cooperation and a way out of the crisis, he was clearly not optimistic about Vladimir Putin's return to the presidency. Nevertheless, Putin's return was marked by meetings and political consultations at the level of ambassadors and employees of MFA of both countries.

The main topics for negotiations in 2012 were issues of bilateral cooperation, energy, increasing trade turnover, and regional issues, but most of the attention was paid to the situation around Syria (Official Website of The President Of The Russian Federation, 2013). It is worth noting that there were serious differences between the two States on the Syrian issue. UK, as a conductor of Western interests, has been actively engaged in diplomatic work with Moscow throughout the conflict, trying to persuade it to look at the Syrian crisis "through the eyes" of the West (RIA, 2012).

The authorities of the UK explained their interest in Syria, primarily to protect the right of the Syrian people for a peaceful democratic existence, which he is not able to provide the regime of President Bashar al-Assad. But the UK undoubtedly had other interests in Syria and the region. Britain tried to use the emergence of training bases for jihadists in Northern Syria to substantiate a threat to its national security. As for the interests that are not publicly advertised, the following trends can be observed. First, there was clearly an interest in the UK and the West as a whole in strengthening their influence on the countries of the Middle East region, the desire to strengthen their military-strategic and geopolitical positions there. Second, resolving the Syrian conflict in favor of the West would increase pressure on Iran, which both the US and the UK were interested. Third, the UK was 
interested in access to Syrian oil and control of oil flows passing through the country (Muradyan, 2012).

The UK has been putting diplomatic pressure on Russia to accept Western projects for a Syrian settlement more favourably. However, Russian diplomacy, which has already learned lessons from the Libyan crisis, continued to pursue its strategic line. In General, Russia blocked three UN Security Council resolutions that were fully supported by the British government.

However, all these differences pale in comparison with the Ukrainian crisis, which has so increased the degree of tension in Russo-British relations that it has reached a critical point. The armed conflict in Ukraine caused an extremely wide international response and, most importantly, it was negative for Russia. The situation worsened after the annexation of Crimea by Russia in 2014, which was not recognized by most of the international community (BBC, 2019). The Russian leadership, justifying the fact of annexation of Crimea, referred to the UN Charter and the 1970 Declaration on principles of international law, which enshrined the right of Nations to self-determination. According to the Russian leadership, this was implemented in extreme conditions in a situation where the right to self-determination could not be realized within Ukraine. In addition, Russia appealed to the precedent of recognizing the unilateral Declaration of sovereignty in Kosovo (Official Website Of The Permanent Mission Of Russia To UNESCO, 2014).

The events of 2014 showed that the UK is quietly using sanctions as a tool of foreign policy. The UK was one of the first countries to condemn the annexation of Crimea and put forward charges against Russia for interfering in the Internal Affairs of Ukraine. London suspended licenses for direct deliveries to Russia of military items that could be used against Ukraine, imposed financial sanctions, and banned investment in the Peninsula. Cooperation with Russia in the energy and military spheres was limited. Several companies were also sanctioned, as well as some politicians and businessmen (Kommersant, 2015).

The British government has repeatedly stated that the EU should be more wary of Putin than, for example, ISIL, since Russia's seizure of Crimea was the first forcible annexation of a European country's territory since 1945. Boris Johnson even wrote a special article accusing Russia of violating International Law (Johnson, 2018). Even 5 years after the reunification of Crimea with Russia, the UK continued to criticize Moscow for this step. According to British Foreign Minister, Jeremy Hunt, his country will never recognize the illegal annexation of Crimea (Interfax, 2019).

Since 2016, the UK has become more focused on events taking place inside the country, where dissatisfaction with EU membership has increased 
amid the crisis. It is known that the UK decided to leave the EU after the referendum in 2016. It is worth noting that Russia was interested in restoring full-fledged relations with the UK, but the possible problems due to Brexit for European countries were more important to Russia than Brexit itself. According to Putin, the implementation of Brexit will undoubtedly affect Russia in political terms to a minimal extent, but this event will have an impact on the world economy ().

The fall in the value of the pound due to Brexit may attract more Russian companies to Britain, as well as cause an influx of Russian players to the London stock exchange. In this case, it will obviously entail further simplification of visa policy and expansion of business contacts, which may in the future contribute to the improvement of Russian-British political relations. However, Russia may lose its planned foreign exchange earnings, as Gazprom and its Nord Stream-2 project may suffer the most. It soon became clear that the UK was determined to maintain the "Crimean" sanctions against Russia even in the event of Brexit (Deutsche Welle, 2016).

The British government in an ultimatum demanded that Moscow admit to involvement in the attempt or confirm that it had lost control of its chemical developments of a military nature. Russia did not respond to the ultimatum, and Britain later submitted the incident to the UN Security Council for discussion.

But the main blow was already dealt to the already fragile political relations: the complete rejection of high-level contacts and the expulsion of 23 Russian diplomats from the country, after which relations fell to a record low. Moscow's response was to mirror the expulsion of the same number of employees of the British diplomatic mission, revoke consent to open the Consulate General in St. Petersburg and close the British Council in Russia. The UK responded by preparing a package of tough new sanctions (TASS, 2016). In turn, the Russian side offered to conduct a joint investigation of the incident, but, as is known, the UK ignored these initiatives and denied access to the Skripals to Russian diplomats (RIA, 2016).

Unfortunately, 2018 turned out to be quite critical for bilateral relations. In November 2018, Russia was again criticized by the UK over an incident in the Kerch Strait. In October 2018, the European Parliament called Russia's actions a "de facto blockade" of the Strait (The Incident in the Kerch Strait: Who's right?, 2018). As a result, the EU increased sanctions "in connection with actions that undermine or threaten the territorial integrity, sovereignty and independence of Ukraine" (BBC, 2019).

To sum up, we can conclude that a series of events, undoubtedly dealt a strong blow to the bilateral political relations, which by the end of the third term of President Vladimir Putin was at a very low level. Despite the fact that the economies of both countries were still open to cooperation. 
Our results correspond to the conclusions of a number of researchers. As we have already pointed out above, since 2014, UK has actively supported the policy of sanctions. We can agree that this was primarily due to claims to counter the "Russian threat" in the Baltic region, Ukraine and in Syria (Andreeva, 2018). In previous years, the US strategy usually helped to "push" its allies, including the UK, to take a tougher position towards Russia (Penkovtsev and Shibanova, 2015).

As T. N. Andreeva points out, Theresa May strongly opposed D. Trump's agreement with the Russian policy of keeping B. Assad as the head of Syria, which the previous American administration did not agree with for many years (Andreeva, 2018).

Nevertheless, in our opinion, Russia and the UK still have some overlapping vectors of foreign policy interests, for example, in countering the risks of radical Islamism in the Middle East (Beloglazov, 2015).

In our view, the crisis of the UK's political institutions can also have an impact on improving Russo-British relations. O. Kharitonova's research shows a decrease in citizens' confidence in political institutions and political forces in the UK against the background of the protracted process of leaving the EU (Haritonova, 2020). Although this is not currently observed, in the future, the search for answers to the challenges of Brexit may well push the British establishment to find ways to normalize relations with Russia.

Our position is in tune with the results of the study by E. S. Khesin, who stressed that the decision to leave the EU caused a decline in economic growth in the UK, starting in 2017, it creates uncertainties that lend a "window of opportunity" for further technological transformation of the country's economy, which can negatively affect its competitiveness in the world (Hesin, 2018). Increasing competition for markets in developing countries dooms the British economy to search for ways to overcome artificial sanctions barriers in relations with Russia (Glushkova et al., 2019). This creates an additional economic interest in establishing normal trade and economic relations with Russia. Economic bilateral relations can theoretically become a kind of "locomotive" that pulls political relations between countries.

\section{Conclusions}

In general, we have concluded that, despite the deepest crisis in modern Russo-British relations, we nevertheless see certain opportunities for their normalization in the future, given the impact of the pandemic factor on the world economy. Such potential opportunities are indicated by a number of objective circumstances. The crisis that was going through the bilateral relations in 2012-2018. and the negative consequences of which we are still seeing can be overcome relatively quickly under certain conditions. 
In general, the study obtained interesting results about the nature and dynamics of Russian-British relations in 2012-2018, which can be useful for researchers to analyze factors and trends in the development of bilateral relations between Russia and the UK and their prediction in the future.

\section{Acknowledgements}

The work is performed according to the Russian Government Program of Competitive Growth of Kazan Federal University.

\section{Bibliographic References}

ANDREEVA, Tat'yana N. 2018. "Politika pervogo kabineta T. Mej v oblasti oborony i bezopasnosti" In: Mirovaya ekonomika i mezhdunarodnye otnosheniya. Vol. 62, No. 6, pp. 45-55.

BBC. 2019. Kerch sanctions: how the US, Canada and EU responded to the incident in the Black sea. Available online. In: https://www.bbc.com/ russian/news-47553843. Consultation date: 08/03/2020.

BELOGLAZOV, Albert. 2015. "Russia's policy on providing security in Central Asia at the beginning of the XXI century" In: Journal of Sustainable Development. Vol. 8, No. 4, pp. 225-232.

GLUSHKOVA, Svetlana; OKSANA, Lomakina; TATYANA, Sakulyeva. 2019. "The economy of developing countries in the context of globalization: Global supply chain management” In: International Journal of Supply Chain Management. Vol. 8, No. 1, pp. 876-884.

HARITONOVA, Elena. 2020. "Politicheskaya situaciya v Britaniya cherez prizmu obshchestvennogo mneniya” In: Sovremennaya Evropa. Vol. 1, No. 94, pp. 123-135.

HESIN, E.S. 2018. "Velikobritaniya: izmenenie ekonomicheskogo landshafta" In: Mirovaya ekonomika i mezhdunarodnye otnosheniya. Vol. 62, No. 11, pp. 5-14.

INTERFAX. 2019. The British Foreign Office said that they would never recognize the reunification of Crimea with Russia. Available online. In: https:// www.interfax.ru/world/654724. Consultation date: 08/03/2020.

JOHNSON, Boris. 2018. Four years since the Illegal Annexation of Crimea. Official website of the UK Government. Available online. In: https:// www.gov.uk/government/speeches/four-years-since-the-illegalannexation-of-crimea-article-by-boris-johnson. Consultation date: 08/03/2020. 
Vasil Timerjanovich Sakaev, Oksana Sergeyevna Demianko y Rushana Alfredovna Faizullina President Vladimir Putin's Third Term (2012-2018)

KOMMERSANT. 2015. What you need to know about sanctions against Russia. Available online. In: https://www.kommersant.ru/doc/2975263. Consultation date: 08/03/2020.

MURADYAN, I. 2012. Combination of interests in Syria. Lragir. Available online. In: http://www.lragir.am/russrc/comments25924.html. Consultation date: $08 / 03 / 2020$.

OFFICIAL WEBSITE OF THE PERMANENT MISSION OF RUSSIA TO UNESCO. 2014. Legal justification of Russia's position on Crimea and Ukraine. Available online. In: http://www.russianunesco.ru/rus/ article/1636. Consultation date: 08/03/2020.

OFFICIAL WEBSITE OFTHE PRESIDENT OF THE RUSSIAN FEDERATION. 2013.Meeting with Prime Minister David Cameron. Available online. In: http://kremlin.ru/events/president/news/19164. Consultation date: 08/03/2020.

PENKOVTSEV, Roman V; SHIBANOVA, Natalia A. 2015. "Wars and military conflicts of the XXI century in the context of the strategic interests of the United States" In: Journal of Sustainable Development. Vol. 8, No. 4, pp. 164-168.

RIA. 2012. Putin and Cameron instruct diplomats to find acceptable solutions to Syria. Available online. In: https://ria.ru/20120802/715147785.html. Consultation date: 08/03/2020.

RIA. 2016. Interstate relations of Russia and the UK. Availableonline.In: https:// ria.ru/20190628/1555970594.html. Consultation date: 08/03/2020.

TASS. 2016. The Skripal Case: London's reaction, Moscow's position and diplomatic consequences. Available online. In: https://tass. $\mathrm{ru} /$ mezhdunarodnaya-panorama/5025322. Consultation date: 08/03/2020. 
ISSN 0798-1406 Depósito legal pp 198502ZU132

\section{Cuestiones Políticas}

\section{Planilla de suscripción}

Nombre

Institución

Dirección

Ciudad País

Cheque de gerencia a nombre de: Universidad del Zulia (LUZ),

Facultad de Ciencias Jurídicas y Políticas, Ingresos Propios

Banco Occidental de Descuento, Cuenta corriente № 212700890-9

Tarifa de suscripción por un año (dos números):

Venezuela: Bs. 80 + Envío

Ejemplar solo: Bs. $40+$ Envío

América Latina \$ $40+$ Envío

Resto del mundo $\$ 50+$ Envío

Esta planilla debe ser enviada a la siguiente dirección:

Revista "Cuestiones Políticas"

Facultad de Ciencias Jurídicas y Políticas

Instituto de Estudios Políticos y Derecho Público

Apartado Postal 526, Maracaibo Venezuela

Puede adelantar información por: cuestionespoliticas@gmail.com

loichirinosportillo@gmail.com 